Community: volume 6, nomor 2, Oktober 2020

p-ISSN: 2477-5746 e-ISSN: 2502-0544

\title{
DIVERSIFICATION OF RURAL ECONOMICS IN SABAH: PATTERNS AND DETERMINANTS OF CHANGE.
}

\author{
Ubong Imang \\ Universiti Malaysia Sabah \\ ubong@ums.edu.my
}

\begin{abstract}
Economic diversification is fundamental in driving economic growth in rural areas. Encouragement of and stimulus for the economic diversification in the rural areas allow for the generation of opportunities and new economic chains. Apart from that it will assist in the diversification of the sources of income for the rural population. In Malaysia, apart from emphasising on development policies, economic diversification began to take place in rural areas through positive developments in the economic sectors other than rural agriculture such as tourism as well as small and medium industries. The importance of leveraging on the opportunities and available space has created a need to examine the pattern and defining factors of economic diversity that is taking place in rural areas. The discussion in this article pays attention to the diversification of the economy that is taking place in the rural areas in Sabah by selecting the village of Tambatuon as a study area. In addition to the secondary data, the data is also obtained through observations, involvement in the newly created economic activities and interviews with the village heads and members of the Village Community Management Council (MPKK). The results of the study confirm that economic diversification in rural areas is in place. Most of the new economic activities exist based on the initiative of the villagers who receive support from the Government and non-governmental organisations. Nevertheless, the study also shows that the ongoing economic diversification process is still limited to the horizontal level. Hence, there is considerable potential for economic diversification that can be further expanded to enhance the competitiveness of the rural population in general. In this context, rural residents should be creative by using available local resources from the surroundings to broaden the process of economic diversification. Assistance and external support, especially from the Government, is significant in providing an environment that can stimulate economic growth to ensure that the process of diversifying the economy continues to flourish and becomes sustainable.
\end{abstract}

Keywords: Economic diversification, rural, Sabah 
Community: volume 6, nomor 2, Oktober, 2020

p-ISSN: 2477-5746 e-ISSN: 2502-0544

\section{INTRODUCTION}

The rural sector is important in the development of a country. This is evidenced when the rural development planning agenda is constantly improved in line with the development and progress of a country in order to improve the well-being of the rural population and the development of the country as a whole. In this regard, economic empowerment efforts are often one of the important agendas in improving the wellbeing and sustainability of rural development. Among the popular measures taken by most governments today, in efforts to strengthen the rural economy, is to encourage diversification in the economic sector. Economic diversification-is seen as an effort that can strengthen the network of rural economic systems by opening up opportunities for the growth of the non-agricultural economic sector. Current developments in technology, transportation and the expansion of accessibility to reach facilities are all rural areas goals in making the eceonomy diversity achievement.

In Malaysia, the Rural Development Policy, launched in 2019, makes economic, population and environmental well-being, the main agenda in the development process by 2030. Prosperous rural vision in various aspects, given emphasis in the development policy, reflects the government's desire to bring people in rural areas to both develop in a balanced manner and be comparable to development in urban areas. In line with that, one of the clear cores of development, is to develop a competitive and sustainable rural economy. Encouraging the diversification of the rural economy is one of the strategies given emphasis by the Malaysian government towards achieving the policy goals. Therefore, the discussion in this article focuses on this aspect by emphasizing the aspects of economic diversification, its patterns and determining factors to its change and consolidation.

\section{LITERATURE REVIEW}

Economic diversification is one of the rural development strategies that receive widespread attention from most countries worldwide (Haggblade et al., 2010). Its importance is seen through its ability to drive robust economic growth in rural areas. Thus, policymakers often see efforts to diversify the rural economy as a way out of rural poverty. For example, ILO (2019) argues that diversification of rural economy in agricultural activities and non-agricultural activities has significant potential to reduce poverty, increase the ability of rural people to cope with the volatility of agricultural commodity prices, strengthen food security and improve the quality of life in rural areas. Pingali et al., (2019) also stressed the importance of the role of economic diversification in bringing positive change to rural areas. In this context, he argues that economic diversification in rural areas can lead to overall productivity increase, drive 
Community: volume 6, nomor 2, Oktober, 2020

p-ISSN: 2477-5746 e-ISSN: 2502-0544

structural transformation and eradicate poverty. He also emphasized that efforts to diversify the rural economy would be able to generate employment opportunities in rural areas so as to enable structural transformation taking place. A study by Tarigas (2005) in Indonesia proves that diversification in the coconut crop sector is able to bring about an increase in the income of the farmers involved.

Nevertheless, previous studies have also shown that economic growth through economic diversification does not occur automatically or spontaneously. In fact, it needs to be stimulated to enable its benefits to be fully enjoyed by every layer of population in rural areas. Orboi (2012) argues that the availability of the environment is important in stimulating economic growth through economic diversification that occurs in rural areas. Some researchers, such as Ellis (2000) and Barret et al., (2001), also found that environmental factors such as marketing opportunities, location advantages and level of access to markets and institutions, are among the determinants of economic diversification in an area.

Some researchers do research at individual and household levels. Important determinants that drive diversification at this stage include the level of response to incentives, household characteristics, economy and demographics (Sarah, L., 2015; Hagglade et al., 2007; Khatun and Roy, 2012, Yenesew et al., 2015). In general, these researchers are of the opinion that there is a situation in the context of such factors that attracts and refuses to conduct economic diversification in rural areas at the level under study. For example, according to Sarah (2015), a repulsive factor is a negative factor that forces the rural population to seek alternative economic activities within and outside the current agricultural activities. Haggblade et al., (2007) argue that situations that pose a high risk to the agricultural sector, such as drought, floods and environmental degradation, are among the pushing factors that encourage rural people to seek alternative economic sources. Meanwhile, an attractive factor is the factor that stimulates households to engage in economic activities in addition to those currently working to improve their standard of living. Economic opportunities generated as a result of developments in a country's economic growth, policy stimulus and benefits from new markets are among the factors that can provide a positive stimulus to the rural population to engage themselves to diversify their economic roots in rural areas.

In the Malaysian context, the transition process that took place in rural areas has shown that the role of the agricultural sector is declining. However, there is an increase in diversification in non-agricultural economies, such as the services, retail, business and tourism sectors. The Malaysian Government, through the Rural Development Policy 2030, also pays attention to efforts to diversify the economy in rural areas by focusing on strengthening the added value of the existing economy and encouraging the 
Community: volume 6, nomor 2, Oktober, 2020

p-ISSN: 2477-5746 e-ISSN: 2502-0544

production of new economic resources in rural areas. In this context the Malaysian government through DPLB 2030 generally takes the following steps;

i. Encourage community involvement in Small and Medium Enterprise activities

ii. Supporting entrepreneurship programs

iii. Encourage the development of new sources of growth through strategic cooperation between various parties

iv. Ensuring a conducive infrastructure environment that can support economic growth and new resources in rural areas

v. Encourage the application of the needs of the Industrial Revolution 4.0

In Sabah, the expansion of the agricultural economy to non-agricultural also occurred significantly. However, such a transition is not yet comprehensive; but only significantly concentrated in certain areas. Generally, this process is stimulated by the development of non-agricultural activities in rural areas; especially in the tourism sector. The development and growth in the services sector; especially tourism activities, has given space to rural areas to expand the economic base of its population. Therefore, it is important to examine and understand the ongoing pattern of economic diversification and its determinants to be utilized in rural development planning as a whole.

Based on the discussion in this section, it was identified that the determining factors to the occurrence of rural economic diversification should be seen as a whole and should not be seen from one level only. Accordingly, the writing in this article takes the approach of discussing the process and pattern of diversification that takes place in the study area holistically. In addition, the study of the determining factors that drive the process and form the pattern of economic diversification that is taking place in the study area (in Sabah) also takes into account factors at various levels.

\section{RESEARCH METHODOLOGY}

The data used in this discussion was collected through observations, involvement in village activities and semi-structured interviews. Observations are made in and around the village by paying attention to the type of economic activities carried out by the villagers. The results of the observations were recorded in a field notebook for reference and comparison purposes with the data from the interviews. Interviews 
Community: volume 6, nomor 2, Oktober, 2020

p-ISSN: 2477-5746 e-ISSN: 2502-0544

through appointments with the Village Head, the chairman of the Village Community Management Council (MPKK) and youths who participated in the activities, were conducted based on a list of general questions related to the background of the village economic development and its development in the context of diversification. Meanwhile, involvement in economic activities carried out by the villagers allows data on the implementation of new economic activities and their development to be obtained. In this regard, the activities involved are newly implemented economic activities such as river tubing, river exploration activities and waterfalls. The data obtained from the three techniques mentioned are listed according to the theme before being compared for the purpose of analysis and interpretation. For the purpose of detailed study, a village located in the rural areas of Sabah was taken as a study area, namely, Kampung Tambatuon. Kampung Tambatuon is located about 27 kilometres from Pekan Kota Belud which is the nearest town to this village. The village is located in a valley and is connected by an unpaved road from the main road. The village has about 872 people, more than 90 percent of whom are Dusun. The settlement area of this village is divided into two parts by Sungai Kedamaian. However, in terms of leadership, this village is under one Village Head and MPKK.

\section{RESEARCH RESULTS AND DISCUSSION}

\subsection{Economic Diversification Processes and Patterns}

Based on field observations, the villages studied are located in the valley area. Therefore, this village area and several surrounding villages were once proposed to be developed as a dam area in 2010 for paddy granary irrigation and commercial rice agropolitan projects in Kota Belud District. However, the proposal had to be forgotten because it received opposition from the villagers and some parties; especially from NonGovernmental Organizations. The results of the observations conducted also found that this village is still involved in agricultural activities. The main crops of the villagers are oil palm, rubber, cocoa and rice. However, the villagers have taken a step forward in paddy crops in line with the increasing demand for organic agricultural products by engaging in organic paddy crops and have successfully marketed their unique product of fragrant keladi rice (beras keladi wangi) with a market price of around RM10 for 500 grams. Due to the interest, initiative and determination of the residents, this village is recognized as one of the main targets of organic paddy cultivation in the Kota Belud Integrated Agricultural Development Area (IADA) project.

Apart from agriculture, the village is actively involved in the tourism sector. The involvement of this village in the tourism sector starts from the sensitivity of the 
Community: volume 6, nomor 2, Oktober, 2020

p-ISSN: 2477-5746 e-ISSN: 2502-0544

villagers to the development of the environment and the strength of the resources available around their village. Based on the interview with the Tambatuon Village Head, the development of ecotourism in Tambatuon village is on the initiative of the villagers. Starting with the opening of a homestay house based on the culture and beauty of the village scenery with the background of Mount Kinabalu. Now, ecotourism in Kampung Tambatuon can stand as high as other ecotourism areas in Sabah.
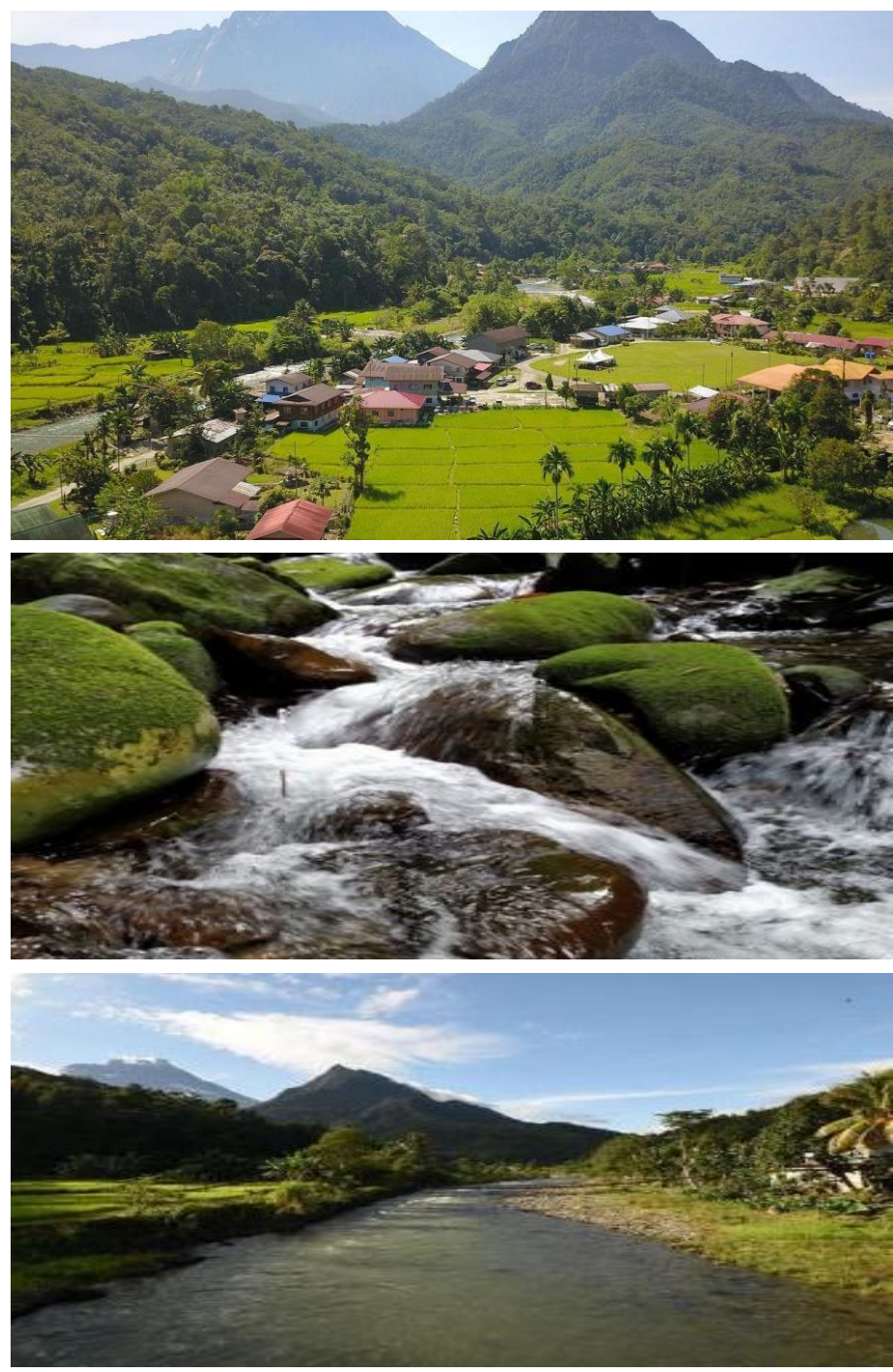

Photo 4.1a: Village Environment 
Community: volume 6, nomor 2, Oktober, 2020

p-ISSN: 2477-5746 e-ISSN: 2502-0544

Table 4.1b: Development of economic diversification patterns from 1950s to 2000

\begin{tabular}{|c|c|c|}
\hline Year & Economic activity & Remarks \\
\hline $1950 \mathrm{~s}$ & $\begin{array}{l}\text { Pagan to Christianity } \\
\text { - New beliefs enable residents to } \\
\text { control fears over wild spirits / forest } \\
\text { rangers } \\
\text { Moving from Hill Area to Valley Area } \\
\text { - Start exploring agricultural land for } \\
\text { rubber and paddy crops } \\
\text { Selling crops in tamu (Sabah } \\
\text { tradisional market) }\end{array}$ & $\begin{array}{l}\text { No outside help } \\
\text { Only agriculture } \\
\text { - Traditional agricultural methods } \\
\text { - Subsistence } \\
\text { Sell crops by walking or via the } \\
\text { river }\end{array}$ \\
\hline $1960 \mathrm{~s}$ & $\begin{array}{l}\text { Getting attention from the } \\
\text { government } \\
\text { - } 1966 \text { primary school developed } \\
\text { - Roads into the village are built } \\
\text { - In addition to rubber and paddy, } \\
\text { residents also garden and grow fruits } \\
\text { - Engage in tamu activities }\end{array}$ & $\begin{array}{l}\text { Farming and selling garden } \\
\text { produce to tamu in Kota Belud. }\end{array}$ \\
\hline $1980 \mathrm{~s}$ & $\begin{array}{l}\text { Agricultural activities } \\
\text { - Rubber } \\
\text { - Paddy } \\
\text { - Palm tree } \\
\text { - Coco } \\
\text { - Fruits }\end{array}$ & $\begin{array}{l}\text { Not much has changed } \\
\text { Use of machinery } \\
\text { Increased convenience }\end{array}$ \\
\hline $\begin{array}{l}\text { 2000- } \\
\text { until } \\
\text { now }\end{array}$ & $\begin{array}{l}\text { Agricultural activities } \\
\text { - Rubber } \\
\text { - Paddy } \\
\text { - Organic rice (unique rice - Yam } \\
\text { coloured rice) } \\
\text { Paddy information centre }\end{array}$ & $\begin{array}{l}\text { The growth of new economic } \\
\text { activities but is horizontal based } \\
\text { on the excess of resources around } \\
\text { the village } \\
\text { Generating new job opportunities }\end{array}$ \\
\hline
\end{tabular}


Community: volume 6, nomor 2, Oktober, 2020

p-ISSN: 2477-5746 e-ISSN: 2502-0544

\begin{tabular}{l|l|l}
\hline Agropelancongan & \\
$\begin{array}{l}\text { Ecotourism } \\
\bullet \text { river tubing } \\
\bullet \text { tracing the river } \\
\bullet \text { waterfall tour } \\
\bullet \text { climbing/hiking Mount Nongkok } \\
\bullet \text { fishing } \\
\bullet \text { Tagal system } \\
\text { Handicraft } \\
\text { Homestay }\end{array}$ & $\begin{array}{l}\text { Utilizing local resources } \\
\text { new branches of the economy } \\
\text { Doing business in the village } \\
\text { Kota Belud soup noodles. } \\
\text { Grocery store }\end{array}$ & NGOs are involved \\
\hline
\end{tabular}
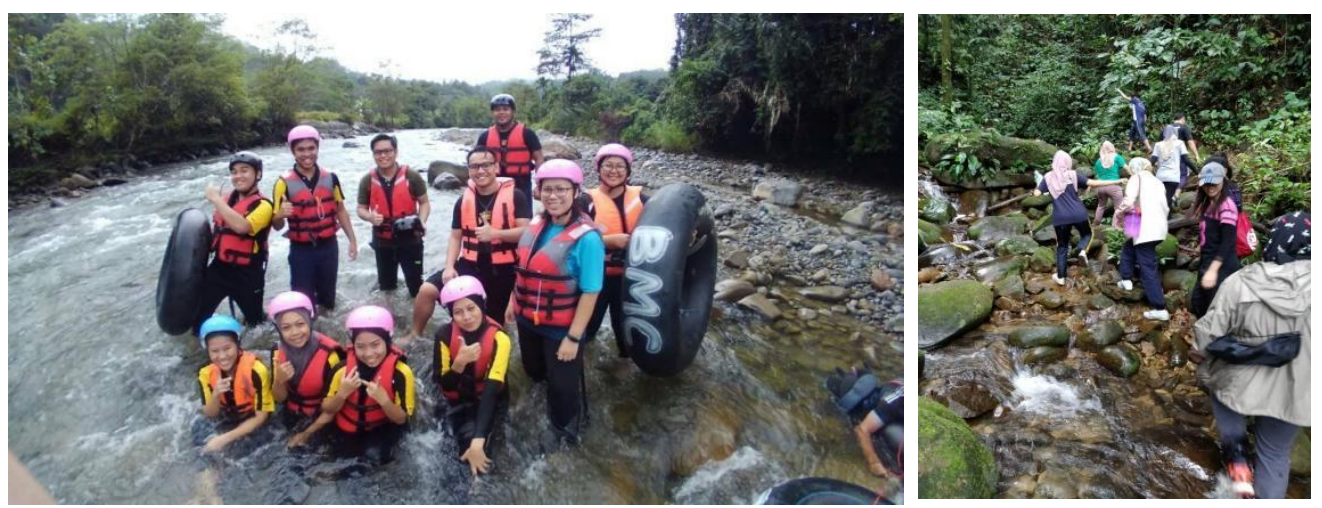

Photo 4.2: Ecotourism activities - river tubing and waterfall tours


Photo 4.3: Agrotourism and homestay 
The results of the study found that many tourism products are developed due to the creativity of the villagers; especially among the youth. Interviews with the Village Head and MPKK found that most of the tourism products created were the result of discussions among the villagers. Among them are river tubing, climbing the crater of Mount Kinabalu; which is Mount Nungkok, exploring rivers and waterfalls and agrotourism. Most of the residents who drive tourism activities in Kampung Tambatuon are among the youth. Based on observations, residents began to create new attractions such as ponds for fishing. In addition, the services provided to tourism have also increased. According to the Village Head, the number of homestays in Tambatuon village and tourists visiting Kampung Tambatuan, whether to enjoy the scenery, climb Nungkok mountain, river tubing and other ecotourism activities, has increased more than double this year. Apart from that, business activities that sell handicrafts and food in Tambatuan village were also created to meet the basic needs of tourists visiting the village.

\subsection{Determinants of Economic Diversification}

It is clear from the discussion in the previous section that economic diversification began to take place in the study area. This can be seen through the existence of new branches of economic resources from the agricultural and nonagricultural sectors. Based on the observations and interviews conducted, the determinants of economic diversification in the study area are largely driven by internal factors. For example, the main driver of the emergence of new sources of economic resources in the study area, such as ecotourism, is initiated by the locals. Many of the young people in the study area are among the educated. Some are the driving force behind the economic activities in the village; especially through the associations they set-up, such as the Binombon Magic Crew Association (BMC).

Activities carried out by young people through this association get support and cooperation from local leaders, such as Village Heads and Village Development Committee Members. In addition, an important asset owned by the study area is the unity among the population. Based on the interview with the Village Head, the villagers are among those who have kinship ties and are of the same origin. The integrity of the relationship among the residents in the study area allows the economic advantages found in their village to be developed together. For example, the natural resources in and around their village, such as Sungai Kadamaian, Kilombon tributaries, mountains, Binombon waterfalls and beautiful scenery around the village, are used as assets for agro-tourism and ecotourism development. These natural resources are shared together for the benefit and development of the local economy. 
Community: volume 6, nomor 2, Oktober, 2020

p-ISSN: 2477-5746 e-ISSN: 2502-0544

The determinants of the economic diversification process in the study area are also contributed to by external factors. Apart from encouragement from the government through the policies and strategies introduced and implemented, as well as the ongoing commitment in providing public and basic facilities that support local economic growth, rapid development in tourism in Sabah and Malaysia has generally provided space for residents in the study area to subsequently develop non-agricultural economic activities in their villages. In addition, Non-Governmental Organizations such as the PACOS Trust and the existence of the Peace Tourism Association (KATA) are also seen to play an important role in helping to expand the economic chain found in the study area. For example, PACOS Trust has introduced organic paddy crops to residents in the study area to become a well-known study area as organic paddy growers in Sabah and the crop yields space in the market inside and outside the study area. In short, support from external factors as discussed in this section provides a positive environment which in turn stimulates the process of economic diversification in the areas studied. With the strength of existing internal factors, the strengthening of the influence of external factors is seen as an important aspect in encouraging the economic diversification process that has begun. After the 50s. Therefore, changes are occured in the study area and rural areas in Sabah and Malaysia as a whole.

\section{CONCLUSION}

Rural areas are currently facing challenges in expanding economic growth, job creation and sustainability. The agricultural sector, which has long been the lifeblood and backbone of rural economic growth, is seen to be increasingly unable to maintain its role as the main driving sector of the economy in rural areas. Economic diversification is one of the interventions that often gets the attention of the government so that rural economic growth remains relevant and continuous by encouraging diversification of the rural economy. Diversification of the rural economy is often referred to as the transition from agriculture to non-agricultural sector activities in rural areas. Economic diversification generally helps to expand economic activities in rural areas, provide new economic opportunities and generate a balanced economy and further strengthen the economy.

Based on the results of the study presented, it is concluded that economic diversification in the study area and rural areas in Sabah as a whole is still in its infancy. The existing pattern of economic diversification shows its limitations and the potential for economic diversification has not yet been fully explored. For example, no agricultural or similar processing activities have been created while the potential for development has existed. The development of the economic diversification pattern discussed also shows the determinants to the occurrence of economic transformation 
Community: volume 6, nomor 2, Oktober, 2020

p-ISSN: 2477-5746 e-ISSN: 2502-0544

starting from the villagers who then intensified efforts with the support of NonGovernmental Organizations and the government. This is because the residents of Kampung Tambatuon have an internal strength that jointly mobilizes economic development activities from the planning stage to its implementation. Therefore, in a broader context, economic diversification is important in ensuring that the rural economy is competitive and provides alternative sources of income to the rural population. As emphasized by Orboi (2012), equipping the environment with the need for the development of economic diversification, such as communication, telecommunications, technology and other assistance, is important in ensuring the continuity of the ongoing economic diversification process in rural areas. However, there is no denying that the continuity of economic activity and its sustainability also depends on many other factors, including the internal factors of the community and the strong support of external agencies, including the role of the government.

\section{REFERENCES}

Barlybaev, A., Akhmetov, V., \& Nasyrov, G., 2009. Tourism as a factor of rural economy diversification. Studies on Russian Economic Development, 20 (6): 639643

Barret, C., Bezunch, M. \& Abdillahi, A., 2001. A income diversification, poverty traps and policy shocks in Cote d'Ivore and Kenya. Food Policy, 26 (4): 367-384

Ellis, F., 2000. Rural livelihood and diversity in developing countries. Oxford: Oxford University Press.

Dasar Pembangunan Luar Bandar. https://www.rurallink.gov.my/wpcontent/uploads/2019/06/BUKU-DASAR-DPLB-2019_new.pdf

Haggblade, S., Hazell, P., \& Reardon, T., 2010. The Rural Non-Farm Economy: Prospects For Growth and Poverty Reduction. World Development, 38 (10): 14291441

Khatun, D., \& Roy, B., 2012. Rural livelihood diversification in West Bengal Determinants and constrains. Agricultural Economics Research Review, Vol. 25 (1): 115-124.

Long, H., Zou, J., Pykett, J., \& Li, Y., 2011. Analysis of rural transformation development in China since the turn of the new millennium. Applied Geography, 31(3): 1094-1105

Pingali, P., Aiyar, A., Abraham, M., \& Rahman A., 2019. Rural Livelihood Challenges: Moving out of Agriculture. In. Transforming Food Systems for a Rising India. 
Community: volume 6, nomor 2, Oktober, 2020

p-ISSN: 2477-5746 e-ISSN: 2502-0544

Palgrave Studies in Agriculture Economic and Food Policy. Palgrave Macmillan, Cham.

Orboi, M. D., 2012. Development of Rural Communities by Diversification of Rural Economy in the Context of Sustainable Development. Scientific Papers: Animal Science and Biotechnologies, 45 (1) : 450-453

Ranis, G., \& Stewart, F., 1993. Rural nonfarm activities in development: Theory and practice. Journal of Development Economics 40(1): 75-101

Reardon, T., Chen, K., Minten, B., \& Adriano, L., 2009. Agrifood industry transformation and small farmers in developing countries. World Development 37(11): 1717-1727

Rosegrant, M., \& Hazel, P., 2000. Transforming the Rural Asian Economy: The Unfinish Revolution. Oxford: Oxford University Press.

Tarigans, D., 2005. Diversifikasi Usahatani Kelapa Sebagai Upaya Untuk Meningkatkan Pendapatan Petani. Perspektif Review Penelitian Tanaman Industri, 4 (2): 70-78.

Sarah Alobo Loison, 2015. Rural Livelihood in Sub-Saharan Africa: A literature Review. The Jurnal of Development Studies, 51:9: 1125-1138. 